\title{
EFL TEACHERS' EXPERIENCES IN DEVELOPING L2 PROFICIENCY THROUGH EXTENSIVE LISTENING
}

\author{
Kukuh Dwi Pamuji ${ }^{a}$ Rob Waring ${ }^{b}$, Eri Kurniawan ${ }^{c}$ \\ ('kukuhdwipamuji@upi.edu; 'cri_kurniawan@upi.edu) \\ School of Postgraduate Studies, Universitas Pendidikan Indonesia \\ Jl. Dr. Setiabudhi 229, Bandung, West Java, Indonesia \\ ( ${ }^{b}$ waring.rob@gmail.com) \\ Notre Dame Seishin University \\ 2-16-9 Ifuku-cho, Kita-Ku, Okayama, Japan
}

\begin{abstract}
Although efforts have been made to investigate the primacy of extensive listening (EL) in developing students' L2 proficiency, the personal experiences of EFL teachers who have successfully developed their L2 through the practice of EL are rarely documented. As this can be a source of inspiration for those struggling to achieve a high L2 proficiency, this study purports to explore how EFL teachers experience the development of their L2 by practicing EL for a considerable amount of time. A Google-form questionnaire with open and closed-ended questions was initially sent to several international groups of EFL teachers via Facebook. In total, 27 participants from six different countries responded to the questionnaire. After a closer look at the initial data, two participants were then selected to provide further insights into their experiences of practicing EL as a means of developing their L2 proficiency. The findings revealed that both teachers used EL because of their joy of listening to compelling listening materials. Practicing their EL routinely with their own degree of intensity, both of them enjoy listening to various audio and video materials with different choices of topics and resources. EL was said to enhance their vocabulary acquisition and help them to develop their other language skills.
\end{abstract}

Keywords: extensive listening, L2 proficiency, personal experiences, EFL teachers

DOI: http://dx.doi.org/10.15639/teflinjournal.v30i2/257-273 
Listening has been seen as a powerful source of comprehensible input for acquiring L2 (Krashen, 1996). Its primacy in L2 acquisition has been reported either empirically or theoretically (e.g. Byrnes, Fink, \& Roman, 1982; Dunkel, 1991; Nagle \& Sanders, 1986; Vandergrift \& Baker, 2015). But in reality, this oral receptive skill has the lowest popularity of all the EFL classroom pedagogies (Vandergrift \& Goh, 2012). The majority of time spent teaching listening has been devoted more to classroom formal instruction with less attention paid to listening beyond the classroom. Unfortunately, in some EFL countries where the teaching hours are limited, the amount of listening practice inside the classroom might not be sufficient for providing students with a plentiful amount of meaningful oral input. Fortunately, there is a solution to this problem. One of the possible alternatives is to provide pleasurable listening activities that students can do at their convenience, anywhere and anytime. Extensive listening (EL) activities might also contribute to the successful acquisition of L2 for those who are not immersed in the formal classroom learning.

Although relatively novel in most Indonesian EFL pedagogies, the practice of EL is reported to enhance students' L2 proficiency in general, familiarize students with the features of spoken language and improve their ability in recognizing words expressed orally (Renandya, 2011; Renandya \& Farrell, 2011; Renandya \& Jacobs, 2016). Some of the recent studies have shown that EL is beneficial for developing L2 listening fluency (Chang, 2012; Chang \& Millett, 2014, 2016; Chang, Millett, \& Renandya, 2018) and promoting learner autonomy (Takaesu, 2013; Widodo \& Rozak, 2016). When the practice of EL is combined with collaborative learning via online media platforms, it could also promote interactions, which could be beneficial for the students' L2 development (Widodo \& Rozak, 2016).

Notwithstanding such potential benefits, the concept of EL and its practice has not yet reached enough EFL classrooms with most EL discussions mainly taking place at university level settings. Most school teachers and students are still not consciously aware of the existence of EL, whereas in reality, the practice is common for those who successfully develop their L2 through enjoyably listening to massive amounts of listening materials, and is a key aspect of L1 acquisition. One reason is that they might not know the concept, or even have not heard the term 'EL' yet but they actually have done it in their daily classrooms. Thus, before engaging in the practical use of EL in classroom 
Pamuji, Waring \& Kurniawan, L2 Proficiency Through Extensive Listening 259

contexts, it is important to gather the personal experiences of those who have engaged in EL. The closest to this are the English teachers themselves.

\section{L2 Listening and Its Pedagogical Implementation}

Comprehensible input is a key aspect of acquiring a second language (Krashen, 1996; Krashen, Lee \& Lao, 2017). Listening is a vehicle of input to develop the students' L2 proficiency (Chang, 2012; Nunan, 2002). Several studies have shown the inextricable linkage between listening and L2 acquisition (e.g. Byrnes, Fink, \& Roman, 1982; Feyten, Johnston, \& Markle, 1992; Jensen \& Finther, 2003; Snyder \& Colón, 1988) and discussion on L2 listening has been widely addressed in the arena of second and foreign language teaching (e.g. Brunfaut \& Révész, 2015; Carrier, 1999; Jung, 2003; Markham, 1999; Saito \& Akiyama, 2018; Sueyoshi \& Hardison, 2005; Vandergrift \& Baker, 2015; Wagner, 2014; Yeldham, 2016). Some practical aspects have also been already discussed, for instance, how discourse signaling cues play a role in L2 listening (Jung, 2003); how captioned videotapes enhance students' word recognition in listening (Markham, 1999); how listener characteristics are related to L2 listening (Brunfaut \& Révész, 2015); and how video-based interaction develops the students' L2 listening comprehension (Saito \& Akiyama, 2018). Given the above evidence, teachers should accept that L2 listening should play an important role in second and foreign language pedagogies.

However, notwithstanding such concerns, the teaching of L2 listening still faces some lingering problems in terms of its practical implementation. Listening is often said to be the most difficult skill to master for many of both second and foreign language students (Vandergrift, 2012). In most classroom settings, the teaching of L2 listening still focuses on students' scores as shown on post-listening comprehension tests, which often lead to increased anxiety (Vandergrift, 2012; Vandergrift \& Goh, 2012). In some EFL countries where the teaching hours are limited, conducting listening activities only inside the class is seen to be not enough. Today's emerging trends in listening are likely to capture this phenomenon and initiate more appreciation of the teaching of listening (Goh, 2018) as students are self-selecting their own listening practice with 'Extensive Listening' (EL). 


\section{Extensive Listening (EL)}

Extensive listening is listening for pleasure; it is listening to a large amount of spoken texts with a focus on getting the information or general understanding of what we are listening to (Renandya, 2011; Renandya \& Farrell, 2011; Renandya \& Jacobs, 2016; Waring, 2008). It is typically done by watching movies, YouTube, TV series, documentary films, TV news, or listening to songs, radio news, online stories, and so forth (Chang, 2018). The essential requirement to say that the listening is extensive is that the level of the material must be suitable to listeners' proficiency; therefore, the listening materials must be selected appropriately (Waring, 2008). If we apply the ten principles of ER by Day and Bamford (2002) to EL, EL should be implemented based on the following ten considerations: 1) the listening materials are easy to comprehend; 2) the listening materials as well as the topics must be highly varied; 3) students select listening materials that they want; 4) students listen to a large amount of spoken texts; 5) listening is for pleasure and to obtain information as well as general understanding; 6) listening is a personal process; 7) listening fluency is achieved by staying within the students' linguistic ability; 8) listening should be done autonomously on the basis of listeners' personal preferences; 9) the presence of teachers is to make sure students are on the right track when doing their listening activities; and 10) the teacher serves as 'an example' for their students. If those aspects are cultivated appropriately, EL can be a fruitful resource for the students to acquire their second language. However, it is not necessary that teachers have to follow all ten of these rigidly, because sometimes listening can be done as a class, or the listening might be assessed. The fundamental aspect is that they listen to a lot of easy materials at the right level. Teachers often find it hard to access EL materials, so listening material can be made easily accessible through the students' own devices, with the help of recent technologies e.g. at elllo.org or er-central.com, and its practice could be managed creatively with a wide variety of activities.

\section{Gaps of Research in Extensive Listening}

Emerging studies have been devoted to investigating the practice of EL in the context of second and foreign language teaching (Alm, 2013; Bidabadi \& Yamat, 2014; Chang, 2010, 2012; Chang \& Millett, 2014, 2016; Chang, Millett, \& Renandya, 2018; Ducker, 2013; Ducker \& Saunders, 2014; Metruk, 
Pamuji, Waring \& Kurniawan, L2 Proficiency Through Extensive Listening 261

2018; Milliner, 2017; Reinders \& Cho, 2010; Renandya \& Farrell, 2011; Widodo \& Rozak, 2016). The growing interests in the area of extensive listening have led several scholars to investigating the role of EL for developing the students' L2 listening fluency (Chang, 2012; Chang \& Millett, 2014, 2016; Chang, Millett, \& Renandya, 2018), the implementation of EL by engaging recent technology (Alm, 2013; Reinders \& Cho, 2010; Widodo \& Rozak, 2016), the use of listening materials and resources for practicing EL (Ducker \& Saunders, 2014; Milliner, 2017; Povey, 2016; Takaesu, 2013; Vo, 2013); and the strategies used by EFL students in practicing EL (Bidabadi \& Yamat, 2014).

Although those studies put an emphasis on the pedagogical implementations of EL, the majority are mainly conducted in university level settings. Moreover, the personal experiences of someone who naturally develops their L2 proficiency through EL are still rarely documented but are necessary. Inspired by one of the Day and Bamford's (2002, p. 139) principles of ER (as adopted into EL) which states that 'the teacher is a role model' for their students, this study delves deeper into EFL teachers' personal experiences of engaging themselves with the practice of EL to develop their L2 proficiency.

There are four research questions to be addressed in this study:

1) How do EFL teachers become more engaged with EL when developing their L2 proficiency?

2) How do EFL teachers implement the practice of EL in their daily routine?

3) What kinds of listening materials and resources do they mostly employ when practicing EL?

4) From their perspectives, what gains are they likely to get from practicing EL?

It is hoped that the teachers' stories of successfully developing L2 proficiency through EL, as well as the obstacles they encounter during its practice, will be a fruitful source of inspirations for those who are struggling to develop their L2 proficiency.

\section{METHOD}

An initial questionnaire was sent to international groups of EFL teachers through the use of Google-form via Facebook. Both open and closed-ended questions were used to get the base data of those who have and have not done EL. At this stage, 27 English teachers participated and 25 of them reported to 
have done EL and enjoy doing it. Based on these initial findings, different follow up questions were made to explore their attitudes and practices toward EL more deeply through personalized one-to-one interviews. Two English teachers were selected on the basis of their degree of intensity of practicing EL and some information they had provided. Both of them were invited via email to confirm their availability of being interviewed through social media platforms. Using a narrative inquiry (Clandinin \& Connelly, 2000), they were interviewed regarding their personal experiences with EL conducted via WhatsApp (participant 1) and Facebook messenger (participant 2). Drawing on Day and Bamford's (2002) ten principles of ER (as adopted into EL), the quantitative and qualitative data were analyzed to outline the EFL teachers' experiences of becoming engaged with EL practice, their way of practicing EL in their daily routine, their preferences of listening materials and the resources they use, as well as their views of what they gain from practicing EL to develop their L2 proficiency.

\section{FINDINGS AND DISCUSSION}

There were 27 EFL teachers from six different countries (Indonesia, Japan, Thailand, Vietnam, Mongolia, and Mexico) who responded to the questionnaire. Those teachers are from several educational institutions (Figure 1). Half of the teachers (14) have been teaching English for more than 10 years, while others have been teaching for 6-10 years (9), 1-5 years (3) and less than one year (1). The majority of them have taken English proficiency tests and identified their level of English as intermediate (5), upper intermediate (11),

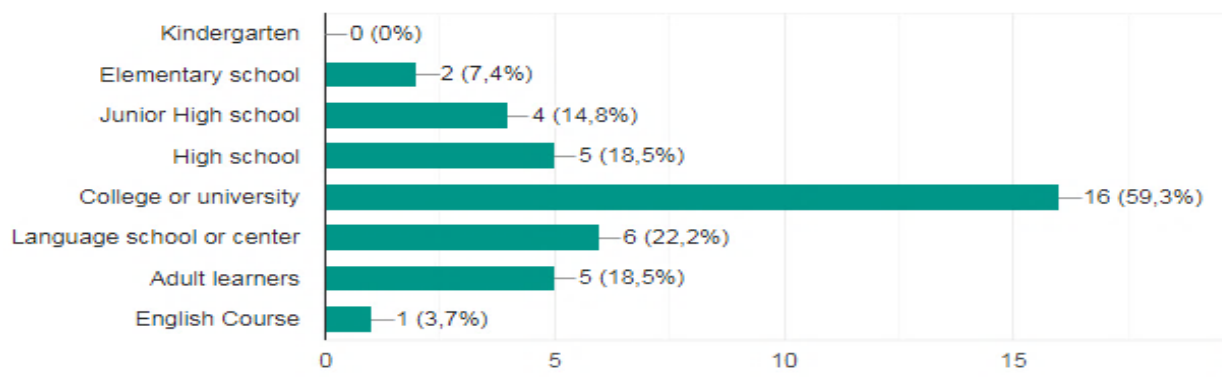

Figure 1. EFL Teachers' Institutions 
and advanced (11). Among them, 13 EFL teachers have heard the term 'EL' and know it very well, 9 of them have heard the term a lot but do not actually know much about it, 3 EFL teachers indicated that they rarely heard the term but are getting to know a bit about it, whereas 2 of them had never heard about it before. Despite the above, all participants reported they have experienced EL with different intensity (Figure 2) in which 9 of them have been doing it routinely for a long time. The majority of them (25) responded positively while the other two indicated that they 'don't enjoy doing EL'.

Among those 25 English teachers, 12 of them started practicing EL when they were at university whereas the others have done EL since elementary schools (6), junior high schools (3), and high schools (2). Some of them also said that they began to like EL since becoming an English teacher (1) and when the apps like YouTube became more accessible (1). Nine EFL teachers have been addicted to EL activities for more than ten years whereas the others have been engaged with EL for 6-10 years (2), 1-5 years (10), and less than one year (4). It was identified that they do EL every day (11), every two days (1), every week (4), and only when they have spare time (9). They have different reasons why they practice EL which include for developing listening fluency, having pleasure and entertainment, becoming familiar with more colligations, enhancing their vocabulary mastery, building up collocation, and picking up some English accents.

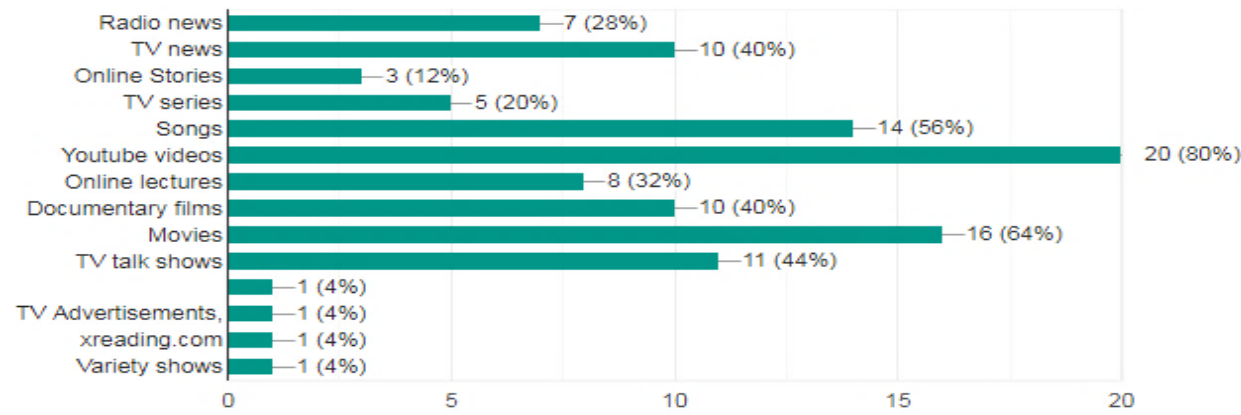

Figure 2. EFL Teachers' Preferences of EL Materials

The teachers have different preferences for audio and video materials for practicing their EL (Figure 2). All of them agreed that EL activities positively contribute to their English proficiency, but this varied from subject to subject. 
Ten EFL teachers indicated that their overall English proficiency improved a lot after practicing EL routinely while 6 teachers felt there were some improvements in their English oral proficiency. The data also revealed that two teachers felt they became more fluent when listening to English audio or video materials and four of them became more familiar with some English words they had never heard before. There were also several teachers who felt they made some improvements after practicing EL, but some others felt that EL had no effect on their proficiency.

\section{Taking a Look at Stories and Experiences}

Based on the initial data, two English teachers were selected for further inquiries by investigating deeper into their experiences of developing L2 through practicing EL. The first was an EFL teacher -Teacher A- who has been teaching English for more than 30 years, has taken most English proficiency tests and identified her level of English as advanced, "I do not mean to brag, but everybody says my English competence is above average." She started to like doing EL from elementary school and has been doing it routinely for a long time, every day. She feels that her overall English proficiency improved a lot after practicing EL routinely. She is now a teacher of EFL in one of Indonesian's most well-recognized English courses. The second was an English teacher-Teacher B-living in Japan, a native speaker of English, who has developed his L2 (Japanese language) through practicing EL. He can do many things with his Japanese language. He is able to follow the news on the radio and enjoys Japanese-spoken performing arts as well as being able to speak well with his friends and family very smoothly and without stress. He feels that EL has helped him in developing his Japanese proficiency.

\section{Engaging with EL to Develop L2 Proficiency}

Teacher A has practiced EL since the fourth grade of elementary school but did not have a partner to interact with to practice her English, so she developed her proficiency through listening and watching English materials. She reflected on the typical way of English teaching at that time, and said that "In my elementary education I just did those receptive skills. No production yet at the time". Through listening to radio news and cassettes, she became 
Pamuji, Waring \& Kurniawan, L2 Proficiency Through Extensive Listening 265

addicted to practicing EL when in junior and senior high school, "... I became so addicted to EL, never missed the news and got more and more cassettes".

Then, she described that her long experiences of practicing EL contributed a lot to her current profession, "As for me I think EL is really helping me a lot to make me who I am now, an English teacher," and her addiction to EL motivates her to still practice it until today, “... . I never let my time pass without doing it. ..." Her other reason for doing so much EL is due to her responsibility as a teacher to broaden her students' knowledge, saying that " $A s$ a teacher you should be many steps, ... . Through EL, I gain a lot of things I can share with my students. They sometimes find the info I pass to them interesting."

Teacher B recalled his experiences learning Japanese in 1998 when he was living in New York. At the time, he only had some Japanese movies and through watching those and repeating the activities, he became familiar with some Japanese vocabulary although he still could not use it well, "Watching those over and over helped me to catch some phrases and vocabulary but I still couldn't function on my own." Then, the very first time he listened to Japanese spoken text was through his tutor who showed him the performance of a Japanese comedy group, "My tutor showed me a comedy group called the Drifters and I thought it was so funny even though I still couldn't understand much. That was probably my first experience listening in Japan. It was certainly a pleasurable experience."

He added that "when I first came to Japan, extensive listening was a way to help me deal with the difficulty of reading material." He began listening to Japanese audio and video materials when his vocabulary had grown and he was able to catch the meaning of what he had listened to. This is in line with what is suggested by Waring (2008) and Renandya (2011) that a key aspect of EL is to listen to easy and comprehensible listening materials. This was shown by Teacher B who started practicing EL when he already had enough vocabulary to understand the materials he listened to. He then became addicted when the radio content was interesting and made him eager to listen to it because of the enchanting stories on the radio, "... They had lots of listeners who would submit their own stories ... that might be touching or might be something funny that they usually had some kind of emotional punchline .... So I started listening to this radio station almost every day and became a really big fan of it." The availability of not only easy, but also interesting and enjoyable listening materials is also a major factor in EL (Renandya, 2011; Renandya \& 
Jacobs, 2016; Waring, 2008), as we saw when Teacher B became addicted to EL because of the interesting stories available on the radio.

\section{Practicing EL in the Daily Routine}

Teacher A practiced EL routinely for an average of 4-5 hours a day using her spare time to do EL activities, "Whenever I have spare time, I do it. Sometimes I stay up late just to watch programs I like." She does his EL practice both in the morning and late at night. "In the morning after I do the household chores I watch Disney Junior with my granddaughter, then when she shifts to YouTube, I watch the News and other programs until around 11. I leave for the office at 11:30 (a.m.)." Usually, she does not do EL in the afternoon because her work as a teacher begins at 1 p.m. After finishing her teaching activities in the office, she continues to do her routine of practicing EL again, "At 9:10 I leave the office and arrive home at 9.40. After doing the cleaning, again I watch TV programs until around 12." A key factor in successfully developing L2 proficiency via EL is listening to a huge amount of materials (Renandya, 2011; Renandya \& Farrell, 2011; Renandya \& Jacobs, 2016). This was shown here by Teacher A who has practiced EL on an everyday basis.

It was also done by Teacher B who until today still listens to Japanese audio and video materials every day by listening to TV programs with his family, "... of course I have daily interaction in Japanese but also probably about 30 minutes to an hour of TV programming in Japanese with my family." He is also still listening to Japanese music while doing his some other works, "Spotify is also something I'm using now for listening to music in Japanese. Often I'll turn it on while I'm grading students' homework." He was actually doing EL every day through listening to podcasts and Japanese audiobooks when he was driving to his office, but since now his work is very close to his home, he does not do it anymore. But he is still thinking of doing it again, "I'm thinking of starting to walk at night and listen to that type of stuff again. It was a relaxing time for me and I can listen to topics that might not be interesting to my wife or eight year old son." In practicing EL today, he usually adjusts it with the schedule of his full-time teaching English, so mostly he does it after coming home and finishing dinner. 
Pamuji, Waring \& Kurniawan, L2 Proficiency Through Extensive Listening 267

\section{Preferences of Listening Materials and Resources}

Teacher A listens a lot to some programs such as Discovery Channel, National Geographic, Animal World, news and movies and obtains lots of information from them. Just for instance, “...from Nat Geo I learn about planets, solar system, weather etc." Then, through Animal World, “...I learn about different kinds of animals and their habitat, how they breed, how they reproduce, how they defend themselves from predators etc." While accompanying her granddaughter watching cartoons from Disney, she also exposes herself to their stories, "I learn a lot of classics such as Snow White, Sleeping Beauty, Red Riding Hood, and many more..." But among all the materials that she listens to every day, English news and songs are the two that she listens to the most. When Teacher A exposed herself to different listening materials, it follows one of the principles of ER (as adopted into EL) by Day and Bamford (2002), which points out the pivotal role played by the presence of a wide variety of materials.

She listens to the news to keep in touch with, “... current issues and environment programs [which] make me up to date and I can also record them for classroom use." She listens to songs not only for entertainment but also to get something that can be implemented to her teaching, "Sweet memories songs and slow rock; they can be used for teaching, too." Following her personal preferences when doing EL, she accesses most of her listening materials through a wide TV screen or desktop connected to the internet, "Well, considering my age... Were I a lot younger, I would prefer to use the smart phone."

Teacher B prefers podcasts as his listening materials because of their similarity to radio, but they can be played repeatedly so that he can obtain the information through listening to it again and again, "...I can always repeat (reply [sic]) it if I didn't catch something or want to listen more closely. These are probably the best for pure listening." This is in agreement with Alm (2013) who reported the positive use of podcasts as a tool for practicing EL. Nowadays, he also prefers watching TV since the content is a little entertaining, "I like TV for it's relaxing quality. Usually the content is rather easy, it's made to be a little suspenseful (did they survive the crash?? etc.)" If the audiobooks are relatively affordable, he is eager to employ them for his EL practice. 
In addition to podcasts, Reinders and Cho (2010) suggested that the use of mobile phones has potential for EL practice. Teacher B does his EL today by accessing the listening materials through his smartphone. He feels that the use of smartphones is pivotal now since they ease our task of checking out the contents that we want to access. Unlike in the past, modern audio and video materials are easier to access since everyone can produce them and share them online, "Before, if you wanted to listen to something you would get an audiobook ... or listen to a radio program. But now tons of people have become YouTubers or bloggers or podcasters ... ." He added that before the era of the smartphone, listening had to be more conscious due to the physical limitations of the devices, but today we can listen through the smartphone while doing some other activities. He said "I'm going to choose topics that have some connection with the people I interact with during my daily life. So issues like local politics could be compelling for me here..." And in selecting materials, he prefers to use those which are affordable and easily accessible.

\section{Gains from Extensive Listening}

For teacher A, EL contributes a lot to her English (L2) proficiency. It helps her to develop her vocabulary as well as her other English skills, "Through EL I enrich my vocabulary, sharpen my listening skills, speed my comprehension ... I try to use new vocab, find the derivation and expand it." She also does such writing activities when doing EL, which help her develop her writing skills, "Listening-writing, I listen to the news items and try to rewrite the content in my own words." She also finds out that EL makes her better at listening to English materials, “..., I find that through leisure listening we can improve our listening skills for sure, better understanding of content matters and since it's done with pleasure it is not burdensome." She is also becoming more confident in using her English, "From EL, I feel that I gain a lot. Confidence, pronunciation improvement and language competence contribute to my self confidence."

EL has really meant a lot for her, and she felt that as a result of routinely practicing EL her English proficiency had benefited her study in the past, "In my younger years I learned at..., and luckily I always got the best student, ... . For my undergraduate degree I also got a full scholarship from ... Also partly from the university where I studied. Thanks to EL." Consistency is one of the key points she underlined when practicing EL, "EL has contributed a lot in the 
Pamuji, Waring \& Kurniawan, L2 Proficiency Through Extensive Listening 269

development of my English proficiency by being open to the real-world issues and being consistent in doing so." To sum up, she suggests those who are still developing their L2 proficiency, to try practicing EL, “...do not be reluctant to practice EL, you will be amazed by how it really improves your proficiency."

For teacher B, he stated that the biggest gain he gets from practicing EL is mainly his vocabulary acquisition. "My personal lexicon of productive Japanese has become quite large. I have a wide range of vocabulary ready to use without hesitation. ... . I took a Japanese vocabulary quiz before and scored about 26,000 words known. ... . My wife who is Japanese and went to university here got 32,000 on the same test." The increasing number of Japanese words that he has mastered gradually made him more fluent when listening to a wide variety of Japanese materials. He felt that his ability to understand input became stronger after practicing EL over a considerable period of time, "That gives me a lot more input than somebody who is limited to just textbook materials."

The more words that he gained from practicing EL also led him to become more aware of various Japanese dialect and accents. In addition, regarding the impact of EL on his oral skills, he felt that EL contributes to his speaking on some other aspects, "To a lesser extent I think that the listening has helped me develop my speaking on a discourse level. ... I think listening to extended texts as made me more capable of engaging in extended speech myself." $\mathrm{He}$ suggested that when developing L2 proficiency, it is necessary for us to find something that we are interested in and enjoy following it in our L2.

EL benefits those practicing it to become more fluent in their L2 listening (Chang, 2012; Chang \& Millett, 2014, 2016; Chang, Millett, \& Renandya, 2018). Both teachers felt that their listening fluency improved after practicing EL, leading them to have a higher understanding of what they are listening to. In addition to benefiting the listening skill, EL is also said to develop overall language proficiency (Renandya, 2011; Renandya \& Jacobs, 2016). Both teachers are able to expand their L2 proficiency in general through practicing $\mathrm{EL}$, but it is not achieved in a relatively short period of time because the gains that we get from EL cannot be perceived immediately (Renandya \& Jacobs, 2016), so commitment and persistence are of paramount importance. 


\section{CONCLUSIONS}

EL serves as a vehicle to convey input through pleasurable activities to assist the acquisition of L2 subconsciously. While some activities of learning a language can be painful and sometimes frustrating, EL provides us with a way of obtaining the language through the motto 'no gain without fun'. From the results of the research, it can be concluded that the benefits from EL do not appear instantly, but after some considerable amount of time as it does in L1. The question then is how to translate it into practical activities in the classroom. The data here show that we should really find something compelling to listen to or watch by getting audio or video materials that make us really enjoy what we are listening to. Once we become addicted and do it regularly, our L2 proficiency will grow effectively without much conscious awareness. The experiences of the two participants above are just some of the few examples of how EL could provide benefits to L2 development. As a follow up to the findings here, it is necessary to translate it into EFL classroom pedagogies by making the teachers be role models for the students first, by enjoying the benefits that we get from EL. As a recommendation, further investigations into how EL is to be implemented in classroom practices especially in the school context are also necessary, to show how EL could be used as a powerful tool to solve the lingering problems of EFL teaching curricula with limited hours of oral-aural language practice.

\section{REFERENCES}

Alm, A. (2013). Extensive listening 2.0 with foreign language podcasts. Innovation in Language Learning and Teaching, 7(3), 266-280.

Bidabadi, F. S., \& Yamat, H. (2014). Strategies employed by Iranian EFL freshman university students in extensive listening: A qualitative research. International Journal of Qualitative Studies in Education, 27(1), 23-41.

Brunfaut, T., \& Révész, A. (2015). The role of task and listener characteristics in second language listening. TESOL Quarterly, 49(1), 141-168.

Byrnes, A. S., Fink, S. R., \& Roman, A. (1982). Enhancing second language acquisition by a focus on listening comprehension: The potential of the cassette. Foreign Language Annals, 15(1), 37-46.

Carrier, K. (1999). The social environment of second language listening: Does status play a role in comprehension? The Modern Language Journal, 
Pamuji, Waring \& Kurniawan, L2 Proficiency Through Extensive Listening 271

83(1), 65-79.

Chang, A. C-S. (2010). Second-language listening anxiety before and after a 1yr. intervention in extensive listening compared with standard foreign language instruction. Perceptual and Motor Skills, 110(2), 355-365.

Chang, A. C-S. (2012). Gains to L2 learners from extensive listening: Listening development, vocabulary acquisition and perceptions of the intervention. Hong Kong Journal of Applied Linguistics, 14(1), 25-47.

Chang, A. C-S., \& Millett, S. (2014). The effect of extensive listening on developing L2 listening fluency: Some hard evidence. ELT Journal, 68(1), 31-40.

Chang, A. C-S., \& Millett, S. (2016). Developing L2 listening fluency through extended listening-focused activities in an extensive listening programme. RELC Journal, 47(3), 349-362.

Chang, A. C-S., Millett, S., \& Renandya, W. A. (2018). Developing listening fluency through supported extensive listening practice. RELC Journal, 117

Chang, A. C-S. (2018). Extensive listening. In J. I. Liontas \& M. DelliCarpini (Eds.), The TESOL Encyclopedia of English Language Teaching. Hoboken, NJ: John Wiley \& Sons, Inc.

Clandinin, D. J., \& Connelly, F. M. (2000). Narrative inquiry: Experience and story in qualitative research. San Francisco, CA: Jossey-Bass, Inc.

Day, R., \& Bamford, J. (2002). Top ten principles for teaching extensive reading. Reading in a Foreign Language, 14(2), 136-141.

Ducker, N. (2013). Self-directed internet-based extensive listening portfolios. In N. Sonda \& A. Krause (Eds.), JALT2012 Conference Proceedings, 516524. Tokyo: JALT.

Ducker, N. D., \& Saunders, J. M. (2014). Extensive listening: Using authentic materials. In N. Sonda \& A. Krause (Eds.), JALT2013 Conference Proceedings, 383-394. Tokyo: JALT.

Dunkel, P. (1991). Listening in the native and second/foreign language: Toward an integration of research and practice. TESOL Quarterly, 25(3), 431-457.

Feyten, C. M., Johnston, J. H., \& Markle, G. C. (1992). Listening and second language acquisition. Middle School Journal, 24(2), 72-75.

Goh, C. C. M. (2018). Listening activities. In J. I. Liontas \& M. DelliCarpini (Eds.), The TESOL Encyclopedia of English Language Teaching (pp. 1-7). Hoboken, NJ: John Wiley \& Sons, Inc. 
Jensen, E. D., \& Vinther, T. (2003). Exact repetition as input enhancement in second language acquisition. Language Learning, 53(3), 373-428.

Jung, E. H. (Sarah). (2003). The role of discourse signaling cues in second language listening comprehension. The Modern Language Journal, 87(4), 562-577.

Krashen, S. D., Lee, S. Y., \& Lao, C. (2017). Comprehensible and compelling: The causes and effects of free voluntary reading. Santa Barbara, CA: ABC-CLIO.

Krashen, S. D. (1996). The case for narrow listening. System, 24(1), 97-100.

Markham, P. (1999). Captioned videotapes and second-language listening word recognition. Foreign Language Annals, 32(3), 321-328

Metruk, R. (2018). Extensive listening practice of EFL learners with authentic English videos. Teaching English with Technology, 18(4), 3-19.

Milliner, B. (2017). Five online resources for extensive listening in the Japanese EFL classroom. Accents Asia, 9, 1-10.

Nagle, S. J., \& Sanders, S. L. (1986). Comprehension theory and second language pedagogy. TESOL Quarterly, 20(1), 9-26.

Nunan, D. (2002). Listening in language learning. In J. C. Richards \& W. A. Renandya (Eds.), Methodology in language teaching: An anthology of current practice (pp. 238-241). New York: Cambridge University Press.

Povey, E. (2016). Extensive listening: Pedagogy, resources, and tools. International Journal of Educational Investigations, 3(7), 35-49.

Reinders, H., \& Cho, M. Y. (2010). Extensive listening practice and inputenhancement using mobile phones: Encouraging out-of-class learning with mobile phones. TESL-EJ, 14(2).

Renandya, W. A. (2011). Extensive listening in the language classroom. In H. P. Widodo \& A. Cirocki (Eds.), Innovation and creativity in ELT methodology (pp. 28-41). New York: Nova Science.

Renandya, W. A., \& Farrell, T. S. C. (2011). "Teacher, the tape is too fast!" Extensive listening in ELT. ELT Journal, 65(1), 52-59.

Renandya, W. A., \& Jacobs, G. M. (2016). Extensive reading and listening in the L2 classroom. In W. A. Renandya, \& H. P. Widodo (Eds.), English language teaching today (pp. 97-110). New York, NY: Routledge.

Saito, K., \& Akiyama, Y. (2018). Effects of video-based interaction on the development of second language listening comprehension ability: A longitudinal study. TESOL Quarterly, 52(1), 163-176.

Snyder, H. R., \& Colón, I. (1988). Foreign language acquisition and audio- 
Pamuji, Waring \& Kurniawan, L2 Proficiency Through Extensive Listening 273

visual aids. Foreign Language Annals, 21(4), 343-348.

Sueyoshi, A., \& Hardison, D. M. (2005). The role of gestures and facial cues in second language listening comprehension. Language Learning, 55(4), 661-699.

Takaesu, A. (2013). TED talks as an extensive listening resource for EAP students. Language Education in Asia, 4(2), 150-162.

Vandergrift, L. (2012). Teaching listening. In C. A. Chapelle (Ed.), The Encyclopedia of Applied Linguistics. Hoboken, NJ: John Wiley \& Sons, Inc.

Vandergrift, L., \& Baker, S. (2015). Learner variables in second language listening comprehension: An exploratory path analysis. Language Learning, 65(2), 390-416.

Vandergrift, L., \& Goh, C. C. M. (2012). Teaching and learning second language listening: Metacognition in action. New York: Routledge

Vo, Y. (2013). Developing extensive listening for EFL learners using Internet resources. Hawaii Pacific University TESOL Working Paper Series, 11, 29-51.

Wagner, E. (2014). Using unscripted spoken texts in the teaching of second language listening. TESOL Journal, 5(2), 288-311.

Waring, R. (2008). Starting an extensive listening program. Extensive Reading in Japan, 1(1), 7-9.

Widodo, H. P., \& Rozak, R. R. (2016). Engaging student teachers in collaborative and reflective online video-assisted extensive listening in an Indonesian initial teacher education (ITE) context. Electronic Journal of Foreign Language Teaching, 13(2), 229-244.

Yeldham, M. (2016). Second language listening instruction: Comparing a strategies-based approach with an interactive, strategies/bottom-up skills approach. TESOL Quarterly, 50(2), 394-420. 